\title{
Systemic inflammation and decline in lung function in a general population: a prospective study
}

\author{
Andrew W Fogarty, Stuart Jones, John R Britton, Sarah A Lewis, Tricia M McKeever
}

Thorax 2007;62:515-520. doi: 10.1136/thx.2006.066969

See end of article for authors' affiliations

Correspondence to: Dr Andrew Fogarty, Division of Epidemiology and Public Health, University of Nottingham, Clinical Sciences Building, City Hospital, Nottingham NG5 1PB, UK; andrew.fogarty@ nottingham.ac.uk

Received 13 June 2006 Accepted 22November 2006 Published Online First 24 January 2007
Background: An increase in levels of C-reactive protein (CRP), a marker of systemic inflammation, is associated with reduced forced expiratory volume in $1 \mathrm{~s}\left(\mathrm{FEV}_{1}\right)$, supporting the hypothesis that the pathophysiology of chronic obstructive pulmonary disease has a systemic inflammatory component. However, few large studies have assessed the relationship between systemic inflammation as measured by CRP and decline in lung function prospectively in a randomly selected population.

Methods: In 1991, data were collected on $\mathrm{FEV}_{1}$ and forced vital capacity (FVC) and a blood sample was taken from 2442 randomly selected adults in a community-based cohort. In 2000 these measures were repeated in 1301 individuals. The level of serum CRP was analysed in these samples from 1991 and 2000. Results: In cross-sectional analyses of data from 1991 and 2000, serum CRP levels were inversely related to $F E V_{1}$ and FVC. After adjustment for smoking and other confounders, the difference in $F E V_{1}$ was reduced by $-9 \mathrm{ml}(95 \% \mathrm{Cl}-13$ to -5$)$ and $-7 \mathrm{ml}(95 \% \mathrm{Cl}-13$ to -2$)$ for each $\mathrm{mg} / \mathrm{l}$ increment in serum CRP in 1991 and 2000, respectively. There was no significant association between baseline serum CRP levels and decline in $\mathrm{FEV}_{1}$ and $\mathrm{FVC}$ over 9 years.

Conclusions: Although serum CRP levels are inversely associated with lung function in cross-sectional studies, there was no effect of a marker of systemic inflammation on decline in lung function over 9 years.
C hronic obstructive pulmonary disease (COPD) is common with a prevalence of $7 \%$ to $23 \%$ of adults. ${ }^{1}$ It is characterised by an accelerated decline in lung function which, in turn, results in an increase in both morbidity ${ }^{1}$ and mortality. ${ }^{2}$ The most important risk factor for COPD is cigarette smoking, and for many years it was considered that the pathophysiological processes were a consequence of local damage to the small airways. However, cross-sectional studies have shown that a serum marker of inflammation, C-reactive protein (CRP), is inversely associated with forced expiratory volume in $1 \mathrm{~s}\left(\mathrm{FEV}_{\mathrm{I}}\right)^{3}$ and is increased in those with a diagnosis of $\mathrm{COPD}^{4-6}$ an observation that supports the concept that there is a systemic inflammatory response in COPD. If systemic inflammation is contributing to the pathophysiology of COPD, this would provide a rationale to consider using novel therapeutic interventions that target this response. To date, however, there have been few large prospective studies of the association between systemic inflammation, as measured by serum CRP, and decline in lung function in a randomly selected population. $^{7}$ We have used data from a longitudinal community-based study to determine whether systemic inflammation as measured by CRP is a risk factor for an increased decline in $\mathrm{FEV}_{1}$ and forced vital capacity (FVC) over 9 years.

\section{METHODS}

\section{Participants}

The participants were drawn from a previously reported cohort of 2633 adults aged 18-70 years living in Nottingham first studied in $1991 . .^{8-10}$ In 2000, all surviving individuals were invited to participate in a follow-up study. ${ }^{11}$ Both studies were approved by the Nottingham City Hospital ethics committee.

\section{Data collection}

In 1991 and 2000, participants were asked to abstain from inhaled bronchodilators for $4 \mathrm{~h}$ and from oral bronchodilators for $8 \mathrm{~h}$ before their appointment. Subjects completed a computer-administered lifestyle questionnaire. $\mathrm{FEV}_{1}$ and FVC were then measured using a dry bellows spirometer (Vitalograph, Buckingham, UK), taking the best of three technically satisfactory manoeuvres with the subject seated. After venesection, serum samples were separated by centrifugation, typically within $15 \mathrm{~min}$, and stored at $-80^{\circ} \mathrm{C}$. These samples were subsequently defrosted and highly sensitive CRP measured using an automated immunoturbidimetric assay on an Olympus AU5400 analyser.

\section{Data analysis}

Smoking status was defined in three categories: current smoker (those who had smoked within 1 month of the study in 1991 or 2000), ex-smoker (those who had not smoked for at least 1 month before the appointment in 1991 or 2000) and never smokers. Smoking data from 1991 were used to validate neversmoking status in 2000. The number of pack-years smoking exposure was estimated for subjects from their reported age at starting smoking, and the usual amount smoked during this period.

Initially, for the 1991 and 2000 datasets, we analysed the cross-sectional association between serum CRP levels and FEV in a multiple linear regression with adjustment for a priori confounding factors of age, sex, height, age squared, age-height interaction, smoking status and total of cigarette pack-years smoked. Potential confounding factors including body mass index (BMI), vitamin $\mathrm{C}$ and magnesium intake were investigated by univariate analysis of the association with CRP and $\mathrm{FEV}_{1}$ and, if a potential confounding effect was identified, they were added to the a priori model. We examined the shape of the relation between CRP and $\mathrm{FEV}_{1}$ by plotting CRP in deciles and linearity was subsequently tested using the likelihood ratio test. As the relation was linear, results were presented both as change in $\mathrm{FEV}_{1}$ per $\mathrm{mg} / \mathrm{l} \mathrm{CRP}$ and graphically in deciles.

Abbreviations: $\mathrm{BMI}$, body mass index; COPD, chronic obstructive pulmonary disease; CRP, C-reactive protein; $F^{\prime} V_{1}$, forced expiratory volume in $1 \mathrm{~s} ;$ FVC, forced vital capacity 
Table 1 Baseline characteristics of study population

\begin{tabular}{|c|c|c|c|c|}
\hline & \multicolumn{2}{|c|}{ Cross-sectional population 1991} & \multicolumn{2}{|c|}{ Cross-sectional population 2000} \\
\hline & Total & $\begin{array}{l}\text { Provided blood } \\
\text { for CRP }\end{array}$ & Total & $\begin{array}{l}\text { Provided blood } \\
\text { for CRP }\end{array}$ \\
\hline Number of participants & 2633 & 2442 & 1346 & 1301 \\
\hline Men, N (\%) & $1312(50)$ & $1224(50)$ & $668(50)$ & $647(50)$ \\
\hline Mean (SD) age (years) & $44.4(13.6)$ & 44.7 (13.5) & $56.1(12.4)$ & $56.1(12.3)$ \\
\hline Mean (SD) height (m) & $1.68(0.1)$ & $1.68(0.1)$ & $1.68(0.1)$ & $1.68(0.1)$ \\
\hline Mean (SD) BMI (kg/m²) & $\begin{array}{l}25.5(4.0) \\
n=2614\end{array}$ & $\begin{array}{l}25.5(4.0) \\
n=2425\end{array}$ & $26.8(4.4)$ & $26.8(4.4)$ \\
\hline \multicolumn{5}{|l|}{ Smoking status, N (\%) } \\
\hline Never & $1306(50)$ & 1201 (49) & $680(51)$ & $654(50)$ \\
\hline Ex & $730(28)$ & $681(28)$ & $510(38)$ & $494(38)$ \\
\hline Current & $597(23)$ & $560(23)$ & 156 (12) & $153(12)$ \\
\hline Mean (SD) FEV 1 (l) & $3.19(0.92)$ & $3.18(0.93)$ & $\begin{array}{l}2.84(0.85) \\
N=1343\end{array}$ & $\begin{array}{l}2.84(0.85) \\
N=1298\end{array}$ \\
\hline Mean (SD) FEV 1 in 1991 (I) & _- & - & $3.2(0.84)$ & $3.18(0.85)$ \\
\hline Mean (SD) FVC (I) & $3.94(1.08)$ & $3.94(1.08)$ & $\begin{array}{l}3.67(1.01) \\
N=1342\end{array}$ & $\begin{array}{l}3.67(1.01) \\
N=1297\end{array}$ \\
\hline Mean (SD) FVC in 1991 (I) & - & - & $3.94(1.00)$ & $3.94(1.01)$ \\
\hline Wheeze in past 12 months, $n(\%)$ & $632(24)$ & $596(24)$ & $343(25)$ & $271(21)$ \\
\hline Median (IQR) CRP (mg/l) & - & $1.14(0.55-2.42)$ & - & $1.69(0.80-3.79)$ \\
\hline \multicolumn{5}{|l|}{$\begin{array}{l}\text { Response in } 2000 \text { by deciles of } \\
\text { CRP in } 1991 \text { (\% total) }\end{array}$} \\
\hline $\begin{array}{l}\text { CRP in } 1991 \text { (\% total) } \\
\quad \text { l }\end{array}$ & & & & $116(9.4)$ \\
\hline 2 & & & & $129(10.4)$ \\
\hline 3 & & & & $123(10.0)$ \\
\hline 4 & & & & $132(10.7)$ \\
\hline 5 & & & & $125(10.1)$ \\
\hline 6 & & & & $133(10.8)$ \\
\hline 7 & & & & $129(10.4)$ \\
\hline 8 & & & & $125(10.1)$ \\
\hline 9 & & & & $115(9.3)$ \\
\hline 10 & & & & $107(8.7)$ \\
\hline
\end{tabular}

The subsequent longitudinal analysis used both the 1991 and 2000 datasets. Predicted $\mathrm{FEV}_{1}$ values were modelled in our dataset for each sex in non-smoking, non-asthmatic, nonwheezing individuals with terms for age, height, age squared and age-height interactions. Individual $\mathrm{FEV}_{1}$ values were expressed as the residual difference from the predicted value, and these values were used to create a single value of change in residual by subtracting the 1991 residual from the 2000 residual. Using the data from 1991 and 2000, we used three measures of CRP exposure: the 1991 serum CRP, an average of the 1991 and 2000 serum CRP measures, and the change in CRP between 1991 and 2000. The effect of these exposures on change in residual value of $\mathrm{FEV}_{1}$ was modelled independently using multiple linear regression.

Interactions for gender, smoking status and BMI on the relation between CRP and both cross-sectional and longitudinal measures of lung function were investigated and considered significant at the value of $\mathrm{p}<0.05$. The analyses were carried out using STATA V.9 (Stata Corporation, College Station, Texas, USA).

Using a conservative estimate of $250 \mathrm{ml}$ for the withinsubject standard deviation for change in $\mathrm{FEV}_{1}$ over 9 years, the available maximum sample size of 1230 individuals provides $80 \%$ power to detect a difference in change in $\mathrm{FEV}_{1}$ of $90 \mathrm{ml}$ between the lowest and highest deciles of CRP.

\section{RESULTS}

A total of 2633 individuals provided complete data in 1991 and, of these, $1346(51 \%)$ were followed up and provided further data in 2000 (tables 1 and 2; 4\% of those who had participated in 1991 had died, $7 \%$ had moved from the area, $23 \%$ declined or were unable to participate in the study and $15 \%$ were uncontactable. Three participants could not provide satisfactory lung function measures and were excluded from further analyses. Two thousand four hundred and forty-two (93\%) of those who participated in 1991 and 1301 (97\%) of those who participated in 2000 gave a serum sample for CRP analysis, and 1219 individuals gave a serum sample for CRP analysis in both 1991 and 2000. In 1991 and 2000, those who provided a sample for CRP analysis were representative of the total study population in both years, with a small decrease in the response rate from those who were in the top two deciles of CRP in 1991, with these individuals providing $9.3 \%$ and $8.7 \%$ of the samples in 2000 .

The median serum level of CRP was $1.14 \mathrm{mg} / \mathrm{ml}$ (interquartile range (IQR) $0.55-2.4$ ) in 1991 and $1.69 \mathrm{mg} / \mathrm{ml}$ (IQR $0.80-3.79)$ in 2000, and these values were significantly different $(p<0.001)$. In the 1991 dataset the serum CRP level was associated with BMI $(\mathrm{p}<0.001)$ and dietary magnesium intake $(p=0.003)$. These factors were therefore included as potential confounding factors in subsequent analyses.

\section{Cross-sectional analysis of CRP and lung function}

There was a linear inverse association between CRP and $\mathrm{FEV}_{1}$ (fig $1 \mathrm{~A}$ and B). In 1991, each $\mathrm{mg} / \mathrm{l}$ increase in serum CRP was associated with a $9 \mathrm{ml}(95 \% \mathrm{CI}-13$ to -5$)$ reduction in $\mathrm{FEV}_{1}$. A similar association of a comparable strength was seen in the cross-sectional data from 2000 (table 2). The difference in $\mathrm{FEV}_{1}$ between the highest and lowest deciles of CRP was $-381 \mathrm{ml}$ (95\% CI -478 to -284$)$ in 1991 and $-259 \mathrm{ml}(95 \%$ CI -385 to 132 ) in 2000. A stronger inverse association between the serum CRP level and $\mathrm{FEV}_{1}$ was seen in those with a BMI $<20 \mathrm{~kg} / \mathrm{m}^{2}$ (interaction: $\mathrm{p}=0.015$ in 1991, $\mathrm{p}=0.033$ in 2000) in both the 1991 and 2000 cross-sectional datasets (table 3). Similar trends were observed for the relation between serum CRP levels and FVC (table 3). 
Table 2 Summary of decline in lung function in study population from 1991 to 2000

\begin{tabular}{|c|c|c|c|}
\hline & $\begin{array}{l}\text { Number of } \\
\text { individuals }\end{array}$ & $\begin{array}{l}\text { Mean (SD) decline in } \\
\mathrm{FEV}_{1}(\mathrm{ml})\end{array}$ & $\begin{array}{l}\text { Mean (SD) decline in } \\
\text { FVC (ml) }\end{array}$ \\
\hline Total population & 1343 & $341(291)$ & $274^{*}(391)$ \\
\hline \multicolumn{4}{|l|}{ Gender } \\
\hline Male & 666 & $385(325)$ & 347 (437) \\
\hline Female & 677 & $297(245)$ & $202+(325)$ \\
\hline \multicolumn{4}{|c|}{ Smoking status in 1991} \\
\hline Never & 713 & $310(284)$ & $220 \ddagger(385)$ \\
\hline Ex & 390 & $361(304)$ & $338(409)$ \\
\hline Current & 240 & $397(281)$ & 330 (357) \\
\hline \multicolumn{4}{|l|}{ Age in 1991} \\
\hline $18-30$ & 137 & $238(297)$ & $27 \S(324)$ \\
\hline $30-40$ & 265 & $294(240)$ & $173(303)$ \\
\hline $40-50$ & 376 & $337(250)$ & 280 (339) \\
\hline $50-60$ & 342 & $376(308)$ & $362(400)$ \\
\hline $60-70$ & 223 & 411 (349) & 401 (484) \\
\hline \multicolumn{4}{|c|}{ Decile of CRP in 1991} \\
\hline 1 & 117 & $346(285)$ & $210(415)$ \\
\hline 2 & 131 & $350(265)$ & 244 (397) \\
\hline 3 & 124 & $345(270)$ & 264 (395) \\
\hline 4 & 133 & 381 (316) & 308 (399) \\
\hline 5 & 125 & $353(275)$ & $322(336)$ \\
\hline 6 & 137 & $320(247)$ & 292 (325) \\
\hline 7 & 132 & $305(230)$ & 222 (333) \\
\hline 8 & 126 & $324(258)$ & $294(346)$ \\
\hline 9 & 119 & $333(360)$ & 295 (470) \\
\hline 10 & 109 & 361 (395) & $317(485)$ \\
\hline
\end{tabular}

$\mathrm{FEV}_{1}$, forced expiratory volume in $1 \mathrm{~s} ; \mathrm{FVC}$, forced vital capacity

*Data from 1342 individuals.

†Data from 676 individuals.

†Data from 712 individuals.

§ata from 136 individuals.

- Data from 123 individuals.
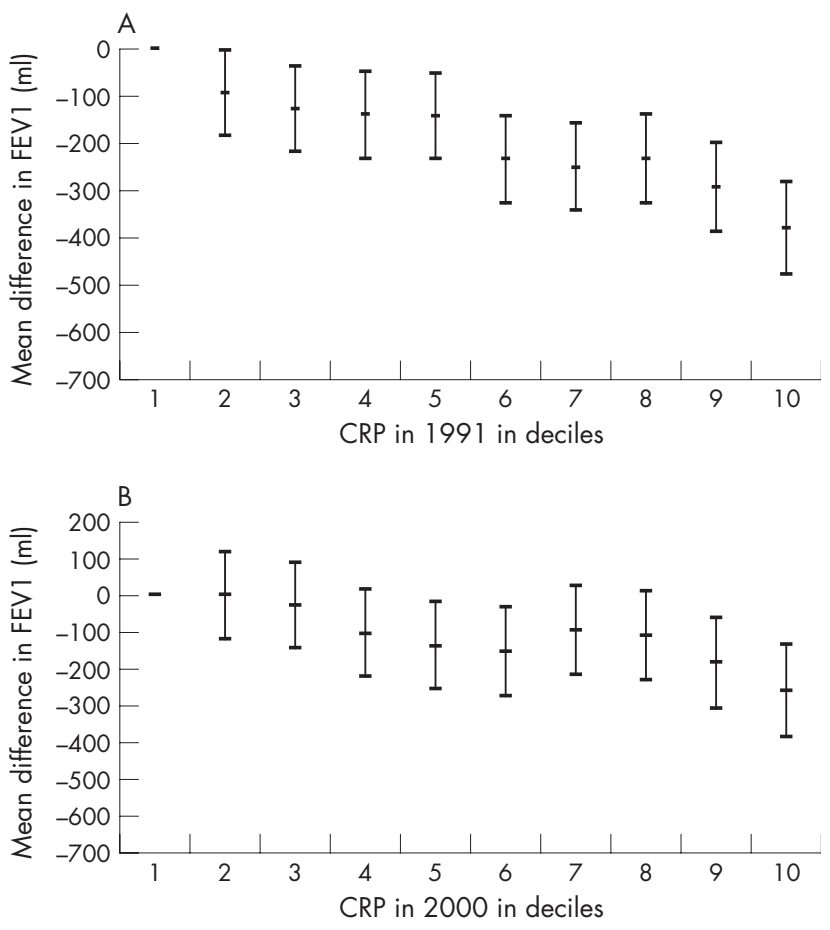

Figure 1 Cross-sectional relation between serum C-reactive protein (CRP) levels $(\mathrm{mg} / \mathrm{l})$ in deciles and forced expiratory volume in $1 \mathrm{~s}\left(\mathrm{FEV}_{1}\right)$ in $(\mathrm{A})$ 1991 and (B) 2000. The lowest decile of serum CRP is the reference value. Analysis adjusted for sex, age, age ${ }^{2}$, height, age-height interaction, body mass index, dietary magnesium intake, current smoking status and number of cigarettes consumed in pack-years.
When the analyses were repeated with the exclusion of those who had self-reported wheeze in the past 12 months, the size of effect of the increase in serum CRP on both $\mathrm{FEV}_{1}$ in both 1991 $(-6 \mathrm{ml}, 95 \% \mathrm{CI}-1 \mathrm{l}$ to -2$)$ and $2000(-5 \mathrm{ml}, 95 \% \mathrm{CI}-1 \mathrm{l}$ to +1$)$, and also FVC in 1991 ( $-8 \mathrm{ml}, 95 \% \mathrm{CI}-14$ to -4$)$ and 2000 ($7 \mathrm{ml}, 95 \% \mathrm{CI}-14$ to 0 ) was decreased.

\section{Longitudinal analysis of CRP and decline in lung function}

There was no effect of CRP on decline in lung function in the total population using either of the two measures of CRP: the baseline 1991 value or the mean of the 1991 and 2000 measurements (table 4). However, there was a significant interaction with gender for FVC with a stronger inverse association in women, although no effect was seen for $\mathrm{FEV}_{1}$. There were no other consistent interactions of the association of serum CRP with either smoking status or BMI on the decline in lung function. There was no association between the change in CRP over 9 years with change in $\mathrm{FEV}_{1}$ when assessed as a continuous measure ($2 \mathrm{ml}$ per $\mathrm{mg} / \mathrm{dl}$ change in CRP, $95 \% \mathrm{CI}-5$ to +1 ), although change in CRP was inversely associated with change in FVC with $-3 \mathrm{ml}$ per $\mathrm{mg} / \mathrm{l}$ change in CRP ( $95 \% \mathrm{CI}-7$ to 0$)$. However, when assessed in tertiles of change in CRP, there was a linear association between change in CRP and change in $\mathrm{FEV}_{1}$ ( $\mathrm{p}$ value for trend $=0.024$ ), with those in the middle and highest tertiles of change in CRP having lost $-31 \mathrm{ml}(95 \% \mathrm{CI}-77$ to +16$)$ and $-53 \mathrm{ml}(95 \% \mathrm{CI}-99$ to $-7)$ respectively compared with the lowest tertile. There was no association between change in CRP in tertiles and change in FVC ( $\mathrm{p}$ value for trend $=0.36$ )

\section{DISCUSSION}

In this study we confirm the findings of a previous crosssectional report that $\mathrm{FEV}_{1}$ and $\mathrm{FVC}$ are inversely associated 
Table 3 Effect of C-reactive protein (CRP, $\mathrm{mg} / \mathrm{l}$ ) on lung function using linear regression in two cross-sectional studies of the Nottingham Lung Health Study population in 1991 and 2000

\begin{tabular}{|c|c|c|}
\hline & $1991(n=2425)$ & $2000(n=1298)$ \\
\hline $\begin{array}{l}\mathrm{FEV}_{1}(\mathrm{ml}) \\
\text { Stratified by smoking } \\
\text { status }\end{array}$ & $-9(-13$ to -5$)$ & $-7(-13$ to -2$)$ \\
\hline \multirow[t]{2}{*}{$\begin{array}{l}\text { Never } \\
\text { Ex } \\
\text { Current }\end{array}$} & $\begin{array}{l}-6(-10 \text { to }-1) \\
-27(-39 \text { to }-15) \\
-9(-20 \text { to }+2)\end{array}$ & $\begin{array}{l}-3(-11 \text { to }+4) \\
-13(-22 \text { to }-4) \\
-5(-28 \text { to }+17)\end{array}$ \\
\hline & $p_{\text {interaction }}=0.005$ & $p_{\text {interaction }}=0.494$ \\
\hline $\begin{array}{l}\text { Male } \\
\text { Female }\end{array}$ & $\begin{array}{l}-13(-21 \text { to }-6) \\
-5(-9 \text { to }-1)\end{array}$ & $\begin{array}{l}-5(-14 \text { to }+4) \\
-10(-17 \text { to }-4)\end{array}$ \\
\hline \multicolumn{3}{|l|}{$\begin{array}{l}\text { Stratified by BMI } \\
\left(\mathrm{kg} / \mathrm{m}^{2}\right)\end{array}$} \\
\hline $\begin{array}{l}>20 \\
20-24.9 \\
25-29.9 \\
>30\end{array}$ & $\begin{array}{l}-28(-60 \text { to }+4) \\
-16(-25 \text { to }-7) \\
-12(-19 \text { to }-5) \\
-3(-10 \text { to }+5)\end{array}$ & $\begin{array}{l}-77(-247 \text { to }+94) \\
+4(-6 \text { to }+14) \\
-6(-14 \text { to }+2) \\
-20(-31 \text { to }-10)\end{array}$ \\
\hline & Pinteraction $=0.015$ & Pinteraction $=0.033$ \\
\hline $\begin{array}{l}\mathrm{FVC}(\mathrm{ml}) \\
\text { Stratified by smoking } \\
\text { status }\end{array}$ & $-11(-16$ to -7$)$ & $-8(-14 \text { to }-2)^{*}$ \\
\hline \multirow{4}{*}{$\begin{array}{l}\text { Never } \\
\text { Ex } \\
\text { Current }\end{array}$} & $-9(-14$ to -3$)$ & $-4(-13$ to +4$)$ \\
\hline & $-31(-45$ to -18$)$ & $-14(-24$ to -4$)$ \\
\hline & $-7(-18$ to +5$)$ & $-10(-36$ to +16$)$ \\
\hline & $p_{\text {interaction }}=0.003$ & $p_{\text {interaction }}=0.459$ \\
\hline $\begin{array}{l}\text { Stratified by gender } \\
\text { Male } \\
\text { Female }\end{array}$ & $\begin{array}{l}-18(-27 \text { to }-10) \\
-5(-11 \text { to } 0)\end{array}$ & $\begin{array}{l}-5(-15 \text { to }+5) \\
-12(-19 \text { to }-5)\end{array}$ \\
\hline $\begin{array}{l}\text { Stratified by BMI } \\
\left(\mathrm{kg} / \mathrm{m}^{2}\right)\end{array}$ & $p_{\text {interaction }}=0.001$ & $p_{\text {interaction }}=0.437$ \\
\hline \multirow[t]{2}{*}{$\begin{array}{l}<20 \\
20-24.9 \\
25-29.9 \\
>30\end{array}$} & $\begin{array}{l}-20(-53 \text { to }+13) \\
-18(-28 \text { to }-8) \\
-16(-24 \text { to }-8) \\
-4(-11 \text { to }+4)\end{array}$ & $\begin{array}{l}-102(-285 \text { to }+80) \\
+4(-8 \text { to }+16) \\
-7(-16 \text { to }+3) \\
-26(-39 \text { to }-13)\end{array}$ \\
\hline & $P_{\text {interaction }}=0.025$ & $P_{\text {interaction }}=0.029$ \\
\hline
\end{tabular}

$\mathrm{FEV}_{1}$, forced expiratory volume in $1 \mathrm{~s}$; FVC, forced vital capacity; BMI, body mass index.

Basic model using $\mathrm{FEV}_{1}$ adjusted for sex, age, age ${ }^{2}$, height, age-height, body mass index and magnesium intake, smoking status (categorical) and smoking pack-years.

*1297 individuals provided data for analysis.

with serum CRP levels after adjustment for smoking, and that this effect is larger in those with a low BMI. For the first time, however, we have been able to examine this association in a prospective dataset and found that, in contrast to the crosssectional data, serum CRP is unrelated to a decline in lung function in a randomly selected population.

The strengths of this dataset are the randomly selected population from the electoral register of a local authority area in Nottingham which is likely to be a representative sample of the general population. While participation in the current study was potentially biased by survival, non-migration and motivation to participate, our data suggest that the participants in 2000 were broadly similar to the original population in terms of diet, smoking history, initial lung function and history of respiratory disease. ${ }^{11}$ Another strength of this study is the availability of archived serum from both 1991 and 2000, and that over $90 \%$ of those who participated in both surveys provided serum for CRP analysis, thus minimising bias. By using two discrete measures of CRP, we are able to get a more precise measure of the total exposure to systemic inflammation over the time period studied. Storage of the serum samples at $80^{\circ} \mathrm{C}$ and testing the assays on the same run permits confidence in the accuracy of the highly sensitive CRP assay. ${ }^{12}$ Our response rate of $51 \%$ of the original study population raises
Table 4 Effect of C-reactive protein (CRP, $\mathrm{mg} / \mathrm{l}$ ) on change in lung function using linear regression between 1991 and 2000

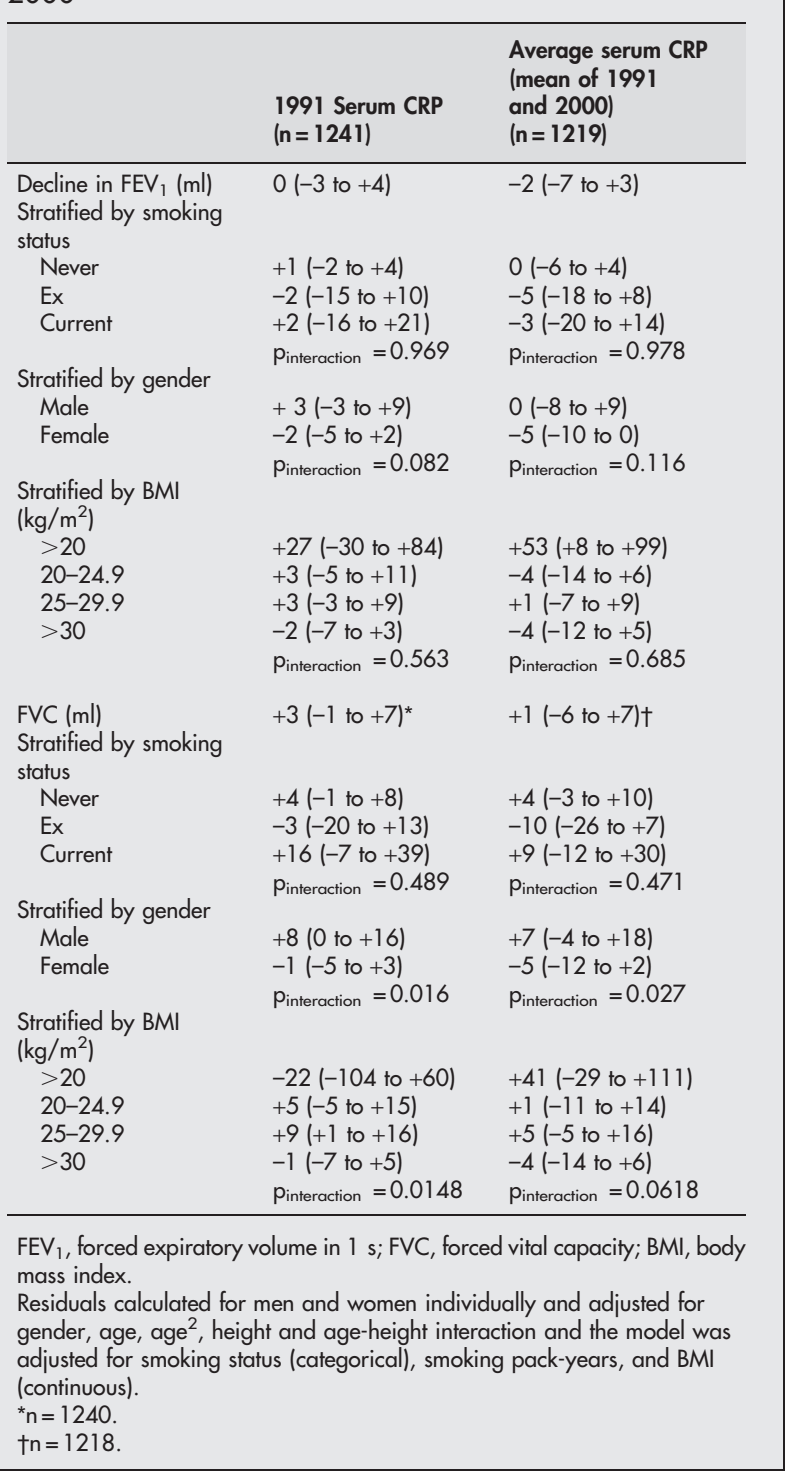

concerns regarding response bias, particularly as elevated serum CRP is a prognostic marker of increased mortality. ${ }^{13}$ In our study population we were able to account for $85 \%$ of the original cohort, of whom $4 \%$ had died and, if the missing $15 \%$ were also deceased, this would be anticipated to bias our results towards observing no effect of CRP on change in lung function over time. We saw little differential in response rates in terms of baseline serum CRP levels, with $44 \%$ of those in the highest decile of serum CRP in 1991 providing data in 2000. Those who responded in 2000 had mean lung function values measured in 1991 that were almost identical to the total population surveyed in 1991, suggesting that there was little difference in those who responded compared with those who did not respond in terms of baseline respiratory function. In addition, we are unable to eliminate the possibility of residual confounding by factors such as plasma glucose which is known to be associated with decreased lung function ${ }^{14}$ and increased CRP. ${ }^{15} 16$

Our observation that there is an inverse association between serum CRP and lung function in the cross-sectional data is consistent with a previous study which used data from 259 
adults who participated in the European Community Respiratory Health Survey of $\mathrm{FEV}_{1} .^{3}$ This demonstrated that mean $\mathrm{FEV}_{1}$ was $3.29 \mathrm{l}$ for those in the highest tertile of serum CRP compared with $3.5 \mathrm{l}$ for the lower two tertiles; the comparable values from our population are $2.88 \mathrm{l}$ and $3.33 \mathrm{l}$, respectively. An increased serum CRP level has also been previously reported in individuals with a diagnosis of chronic obstructive pulmonary disease (COPD). ${ }^{4-6}$ Our data are not consistent with the two previously published studies of systemic inflammation as measured by CRP. One study of 4803 participants in the Lung Health Study demonstrated an accelerated decline in lung function in adults with higher CRP levels, ${ }^{13}$ although the population studied is not directly comparable to ours as they had mild to moderate COPD at baseline and we used a population-based random sample. A recent study from France of 531 participants showed a positive association between the change in CRP level and decline in lung function ${ }^{7}$ when change in CRP was divided into tertiles with a difference of $-100 \mathrm{ml}$, between the highest and the lowest tertiles. Although in our dataset our initial evaluation of the association between change in CRP and change in lung function demonstrated no association, repeating this analysis using tertiles of change in CRP produced a similar result to Shaaban et al, with those in the highest tertile for change in CRP having a decline in lung function of $-53 \mathrm{ml}$ compared with those in the lowest tertile for change in $\mathrm{FEV}_{1}$. The interpretation of this observation is complicated by the increase in median CRP in our population from 1991 to 2000, but the consistency of this observation with previous data suggests that it is not a spurious result. In addition, other studies using plasma fibrinogen, an alternative marker of chronic inflammation, found an association between higher plasma fibrinogen and greater loss of lung function in populations with ${ }^{17}$ and without ${ }^{18}$ COPD. The observation that a BMI of $<20 \mathrm{~kg} / \mathrm{m}^{2}$ is associated with a larger decrease in lung function per unit increase in CRP cross-sectionally is surprising and must be considered with caution. We cannot exclude the possibility that this is a type 1 statistical error. However, this would be one potential explanation for the increased emphysema observed on CT scanning in patients with anorexia nervosa. ${ }^{19}$

The absence of any effect of systemic inflammation as measured by CRP on decline in lung function suggests that there was no association between these two measures, although we cannot exclude the possibility that there is a smaller effect than the $90 \mathrm{ml}$ difference between deciles of CRP which our study was powered to detect. We have to consider how we can reconcile the cross-sectional observation of a consistent inverse association between CRP and lung function in our data and those of others, ${ }^{3-6}$ with the absence of a relation between baseline CRP and decline in lung function. First, it is possible that on the day of measurement a transient phenomenon such as reversible subclinical infection or a minor increase in atmospheric pollution reduced lung function measurements and increased CRP which would have an impact on the crosssectional data but not those acquired over time. Second, it may be that the pulmonary pathophysiology of COPD, particularly at the level of the more vascular small airways and alveoli, is driving the systemic inflammation and the raised serum CRP level simply reflects this process. This would be consistent with the findings of a series of corticosteroid intervention studies in the late $1990 \mathrm{~s}^{20-24}$ at doses that have systemic as well as local activity $^{25}$ but had no significant effect on the long-term rate of decline in lung function, as well as a recent factor analysis suggesting dissociation of lung function and airway inflammation in COPD. ${ }^{26}$ Third, we speculate that other factors such as fetal development may influence the capacity for subsequent inflammatory responses as well as lung growth, and hence maximum lung function acquired, but is less important in influencing the subsequent decline in lung function observed after the age of approximately 25 years. ${ }^{27}$ This hypothesis is supported by the inverse association between birth weight and CRP with a $1 \mathrm{~kg}$ increase in birth weight being associated with a $10.7 \%$ decrease in CRP in a sample of adults aged 30 to 59 years, ${ }^{28}$ and the association of low birth weight with subsequent decreased lung function in adults. ${ }^{29}$ However, to date this hypothesis has not been tested directly in a population with data on birth weight, CRP and decline in lung function. Finally, CRP may not be the most appropriate marker of systemic inflammation and another marker such as fibrinogen ${ }^{17}$ or interleukin-6 that have been reported to be increased in $\mathrm{COPD}^{6}$ may be more sensitive.

In conclusion, we have shown that, while systemic inflammation is inversely related to lung function cross-sectionally, there is no evidence that this is a risk factor for an increased decline in lung function in the population, although we cannot exclude the possibility that this negative finding is a consequence of a healthy survivor effect. The role of systemic inflammation in the pathogenesis of COPD therefore remains uncertain.

\section{Authors' affiliations}

Andrew W Fogarty, John R Britton, Tricia M McKeever, Division of Epidemiology and Public Health, University of Nottingham, Clinical Sciences Building, City Hospital, Nottingham, UK

Sarah A Lewis, Division of Respiratory Medicine, University of Nottingham, Clinical Sciences Building, City Hospital, Nottingham, UK

Stuart Jones, Department of Clinical Chemistry, City Hospital, Nottingham, UK

Tricia McKeever is funded by the Wellcome Trust. The study was funded by Asthma UK, the British Lung Foundation and the University of Nottingham. Competing interests: None.

\section{REFERENCES}

1 Pauwels R, Rabe K. Burden and clinical features of chronic obstructive pulmonary disease (COPD). Lancet 2004;364:613-20.

2 Hole D, Watt G, Davey Smith G, et al. Impaired lung function and mortality risk in men and women: findings from the Renfrew and Paisley prospective population study. BMJ 1996;313:711-5.

3 Kony S, Zureik M, Driss $F$, et al. Association of bronchial hyperrresponsiveness and lung function with $\mathrm{C}$-reactive protein (CRP): a population based study. Thorax 2004;59:892-6.

4 Gan W, Man S, Senthilselvan A, et al. Association between chronic obstructive pulmonary disease and systemic inflammation: a systematic review and a metaanalysis. Thorax 2004:59:574-80.

5 Pinto-Plata V, Mullerova $\mathrm{H}$, Toso J, et al. C-reactive protein in patients with COPD, control smokers and non-smokers. Thorax 2006;61:23-8.

6 Yende S, Waterer G, Tolley E, et al. Inflammatory markers are associated with ventilatory limitation and muscle dysfunction in obstructive lung disease in well functioning elderly subjects. Thorax 2006;61:10-6.

7 Shaaban R, Kony S, Driss F, et al. Change in C-reactive protein levels and FEV (1) decline: a longitudinal population-based study. Respir Med 2006;100:2112-20.

8 Britton J, Pavord I, Richards K, et al. Dietary magnesium, lung function, wheezing, and airway hyper-reactivity in a random adult population sample. Lancet 1994;344:357-62.

9 Britton J, Pavord I, Richards K, et al. Dietary sodium intake and the risk of airway reactivity in a random adult population. Thorax 1994;49:875-80.

10 Britton J, Pavord I, Richards K, et al. Dietary antioxidant vitamin intake and lung function in the general population. Am J Respir Crit Care Med 1995; 151:1383-7.

11 McKeever T, Scrivener S, Broadfield E, et al. Prospective study of diet and decline in lung function in a general population. Am J Respir Crit Care Med 2002;165:1299-303

12 Aziz N, Fahey J, Detels R, et al. Analytical performance of a highly sensitive Creactive protein-based immunoassay and the effects of laboratory variables on levels of protein in blood. Clin Diagn Lab Immunol 2003;10:652-7.

13 Man P, Connett J, Anthionisen N, et al. C-reactive protein and mortality in mild to moderate chronic obstructive pulmonary disease. Thorax 2006;61:849-53

14 McKeever T, Weston P, Hubbard R, et al. Lung function and glucose metabolism: an analysis of data from the Third National Health and Nutrition Examination Survey. Am J Epidemiol 2005;161:546-56.

15 Ridker P, Buring J, Cook N, et al. C-reactive protein, the metabolic syndrome, and risk of incident cardiovascular events. Circulation 2003;107:391-7. 
16 Freeman D Norrie J, Caslake M, et al. C-reactive protein is an independent predictor of risk for the development of diabetes in the West of Scotland Coronary Prevention Study. Diabetes 2002:51:1596-600.

17 Donaldson G, Seemungal T, Patel I, et al. Airway and systemic inflammation and decline in lung function in patients with COPD. Thorax 2005; 128:1995-2004.

18 Thyagarajan B, Jacobs D, Apostol G, et al. Plasma fibrinogen and lung function: the CARDIA study. Int J Epidemiol 2006;35:1001-8.

19 Coxson H, Chan I, Mayo J, et al. Early emphysema in patients with anorexia nervosa. Am J Respir Crit Care Med 2004;170:748-52.

20 Burge $\mathrm{P}$, Calverley $\mathrm{P}$, Jones $\mathrm{P}$, et al. Randomised, double-blind, placebo controlled study of fluticasone proprionate in patients with moderate to severe chronic obstructive pulmonary disease. BMJ 2000:320:1297-303.

21 Pauwels R, Lofdahl C-G, Laitinen L, et al. Long-term treatment with inhaled budesonide in persons with mild chronic obstructive pulmonary disease who continue smoking. N Engl J Med 1999:340:1948-53.

22 The Lung Health Study Research Group. Effect of inhaled triamcinolone on the decline in pulmonary function in chronic obstructive pulmonary disease. N Engl J Med 2000;343:1902-9.
23 Vestbo J Sorensen $T$, Lange $P$, et al. Long term effect of inhaled budesonide in mild and moderate chronic obstructive pulmonary disease: a randomised controlled trial. Lancet 1999;353:1819-23.

24 Highland $\mathrm{K}$, Strange $\mathrm{C}$, Heffner J. Long-term effects of inhaled corticosteroids on $\mathrm{FEV}_{1}$ in patients with chronic obstructive pulmonary disease. Ann Intern Med 2003;138:969-73.

25 Clark D, Lipworth B. Adrenal suppression with chronic dosing of fluticasone propionate compared with budesonide in adult asthmatic patients. Thorax 1997; 52:55-8.

26 Lapperre T, Snoeck-Stroband J, Gosman M and GLUCOLD Study Group, et al. Dissociation of lung function and airway inflammation in chronic obstructive pulmonary disease. Am J Respir Crit Care Med 2004; 170:499-504.

27 Fletcher C, Peto R, Tinker C, et al. Factors related to the development of airflow obstruction. In:The natural history of chronic bronchitis and emphysema. 1 st ed. Oxford: Oxford University Press, 1976:70-102.

28 Sattar N, McConnachie A, O'Reilly D, et al. Inverse association between birth weight and C-reactive protein concentrations in the MIDSPAN family study. Arterioscler Thromb Vasc Biol 2004;24:583-7.

29 Barker D, Godfrey K, Fall C, et al. Relation of birth weight and childhood respiratory disease to adult lung function and death from chronic obstructive airways disease. BMJ 1991;303:671-5.

\section{PULMONARY PUZZLE}

\section{Respiratory disease in the ophthalmology department}

\section{Clinical presentation}

A 24-year-old Indian doctor presented to the ophthalmology department complaining of bright lights in his field of vision during the preceding 6 months. He had previously been diagnosed with inferior branch retinal vein occlusion in his right eye and undergone laser treatment. On examination his visual acuities were $6 / 4$ in the right and $6 / 5+$ in the left eye. On fundoscopy there were multiple areas of sheathing of the retinal veins in both eyes, with small branch retinal vein occlusion in the right eye (fig 1 ).

\section{Question}

What is your differential diagnosis?

See page 526

This case was submitted by:

J K Quint

Department of Academic Respiratory Medicine, Royal Free and University College Medical School, London, UK

A Elsheikh, B Yung, J Samuel, D K Mukherjee Department of Respiratory Medicine, Basildon and Thurrock University Hospital,

Essex, UK

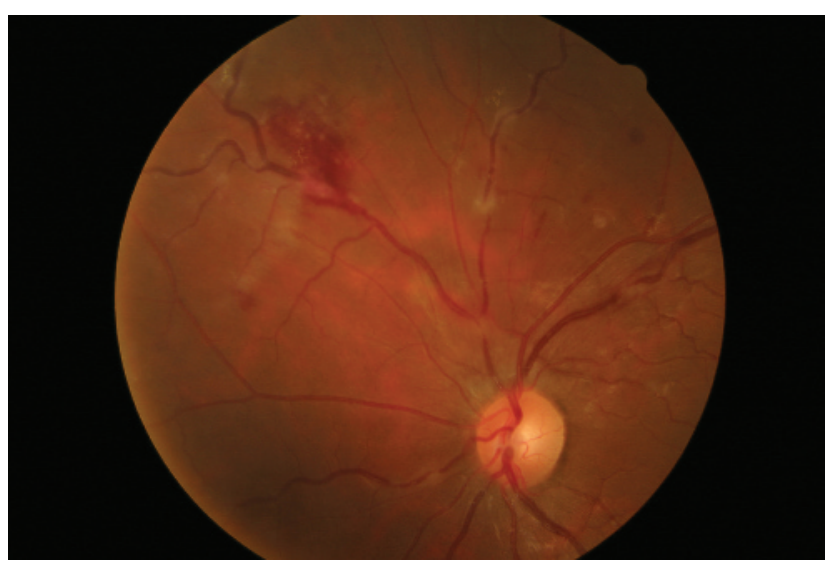

Figure 1 On fundoscopy; multiple areas of sheathing of the retinal veins, with small branch retinal vein occlusion.

Correspondence to: Dr Jennifer Quint, Department of Academic Respiratory Medicine, Royal Free and University College Medical School, Rowland Hill St Hampstead, London NW3 2PF, UK; i.quint@medsch.ucl.ac.uk

doi: $10.1136 /$ thx.2007.082578 